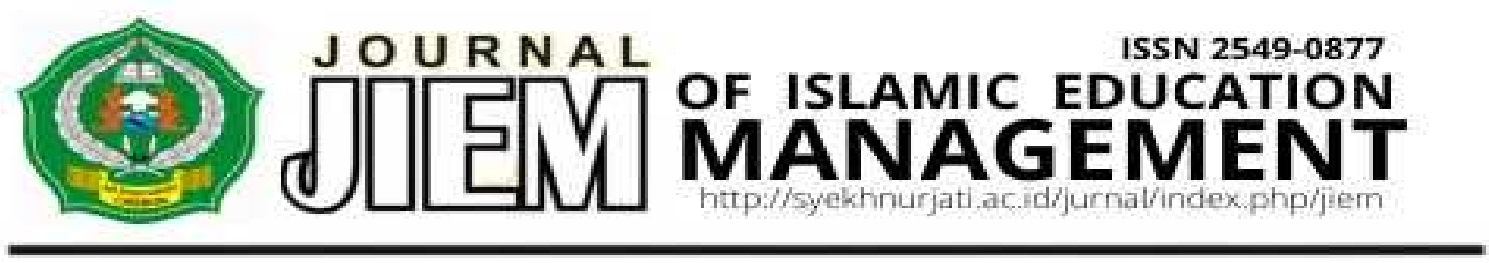

\title{
ANALISIS PROBLEMATIKA PELAKSANAAN SUPERVISI DALAM KEGIATAN PEMBELAJARAN PADA MASA PANDEMI COVID-19 DI MII PURWAWINANGUN CIREBON
}

\author{
Halimatussa'diyyah, Septi Gumiandari* \\ Pascasarjana Institut Agama Islam Negeri (IAIN) Syekh Nurjati Cirebon \\ Halimatussadiyyah96@gmail.com, septigumiandari@gmail.com \\ Corresponding author
}

\begin{abstract}
The implementation of academic supervision is one of the important things to do. With the implementation of supervision, it is hoped that it can provide assistance and breakthrough solutions to educational problems and improve the performance of teachers in the learning process. This study aims to determine the problems with the implementation of academic supervision during the Covid-19 pandemic at MI Islamiyah Cirebon. To achieve this goal, this study uses a qualitative approach with phenomenological descriptive analysis. Data collection techniques were carried out through interviews and documentation studies. To obtain comprehensive data, researchers used triangulation to support the credibility and validity of the data obtained. The results of the study stated that: (1) the problems found in implementing academic supervision during the Covid-19 pandemic are the difficulty in implementing the national curriculum in the midst of the Covid-19 pandemic, teachers' unpreparedness in carrying out online learning, teachers; technology savvy, technical differences in the implementation of learning for each school that cause contra for the parents, understanding of the material which cannot be absorbed optimally, teachers' difficulty in assessing the development of students' affective attitudes; (2) efforts to overcome the problems of academic supervision are replacing the national curriculum with the Covid19 emergency curriculum, providing guidance and direction related to the use of technology, and implementing face-to-face learning twice a week.
\end{abstract}

Keywords: Supervision Problems, Academic Supervision, Covid-19 Pandemic

\begin{abstract}
Abstrak
Pelaksanaan supervisi akademik menjadi salah satu hal yang penting untuk dilakukan. Dengan dilaksanakan supervisi diharapkan dapat memberikan bantuan dan terobosan solutif terhadap permasalahan pendidikan dan memperbaiki kinerja para guru pada proses pembelajarannya. Penelitian ini bertujuan untuk mengetahui problematika pelaksanaan supervisi akademik selama masa pandemi Covid-19 di MI Islamiyah Cirebon. Untuk mencapai tujuan tersebut, penelitian ini menggunakan pendekatan kualitatif dan analisis yang digunakan yaitu deskriptif fenomenologis. Teknik pengumpulan data dilakukan melalui wawancara dan studi dokumentasi. Untuk pemerolehan data secara komprehensif, peneliti menggunakan triangulasi untuk mendukung kredibilitas maupun keabsahan data yang
\end{abstract}


diperoleh. Hasil dari penelitian menyatakan bahwa : (1) problematika yang ditemukan dalam pelaksanaan supervisi akademik pada masa pandemi Covid-19 antara lain: sulitnya pelaksanaan kurikulum nasional ditengah pandemi Covid-19, ketidaksiapan guru dalam melangsungkan pembelajaran online, masih terdapat guru yang gaptek teknologi, perbedaan teknis pelaksanaan pembelajaran tiap sekolah yang menimbulkan kontra bagi orangtua siswa, pemahaman materi tidak bisa diserap secara maksimal, guru tidak bisa menilai perkembangan sikap afektif siswa (2) usaha-usaha untuk mengatasi problematika supervisi akademik antara lain: mengganti kurikulum nasional dengan kurikulum darurat Covid-19, pemberian bimbingan dan arahan terkait pemanfaatan teknologi, dan pelaksanaan pembelajaran tatap muka dilakukan sebanyak $2 x$ dalam seminggu

Kata Kunci: Problematika Supervisi, Supervisi Akademik, Pandemi Covid-19.

\section{A. PENDAHULUAN}

Dunia pendidikan menjadi sektor yang sangat berpengaruh terhadap pembentukan kualitas manusia yang berkarakter dan unggul bagi peradaban manusia. Sukses dan majunya suatu Negara tak terlepas dari peran pendidikan yang menyertainya yang mendukung potensi-potensi yang ada dalam diri manusia. Hal tersebut senada dengan yang disampaikan oleh Alpian et al (2019:67) yang menyatakan bahwa peran dan fungsi pendidikan dalam kehidupan mausia sangat besar sekali dalam menyiapkan dan mebentuk Sumber Daya Manusia (SDM) yang berkualitas dan unggul sehingga mampu menjadi insan yang dapat bersaing dan juga memiliki rasa solidaritas dan tenggang rasa yang tinggi.

Pada tahun 2019 secara tidak terduga terjadi wabah Covid-19 yang muncul dan membuat semuanya berubah dalam sekejap. Adanya pandemi covid-19 yang memasuki Indonesia membawa dampak yang sangat signifikan dalam seluruh lapisan kehidupan, termasuk dalam hal dunia pendidikan di Indonesia juga ikut terkena dampak dari adanya wabah
Covid-19 ini. Menyikapi kondisi tersebut pemerintah memberikan solusi kebijakan pendidikan yang baru di masa pandemi ini yaitu dengan mengeluarkan sebuah kebijakan e-learning sebagai suatu langkah untuk mencegah penyebaran Covid-19 di dunia pendidikan. Pernyataan tersebut didukung oleh Anugrahana (2020:282) yang menyatakan bahwa Pandemi Covid-19 sudah merambah pada dunia pendidikan, oleh sebab itu pemerintah pusat sampai pada tingkat daerah memberikan kebijakan dengan meliburkan seluruh lembaga pendidikan dan mengubah strategi pembelajaran yang awalnya adalah tatap muka dengan mengubah menjadi pembelajaran non-tatap muka (online) sebagai upaya mencegah meluasnya penularan Covid-19.

Terkait pelaksanaan kebijakan pandemi covid-19 yang telah diberlakukan dan diterapkan terhitung dari bulan maret hingga sekarang tentunya ada berbagai tantangan yang dihadapi oleh kepala sekolah dan siswa selaku pelaksana dalam kebijakan tersebut salah satunya yaitu terkait pelaksanaan supervisi akademik di sekolah yang tidak bisa berjalan seperti 
biasanya dikarenakan kondisi aktivitas belajar mengajar yang berbeda.

Pelaksanaan supervisi menjadi salah satu proses yang tidak bisa dilepaskan dari aktivitas pendidikan yang sedang berjalan. Sekolah yang menginginkan kualitas mutu yang baik maka proses supervisi harus dilaksanakan secara baik pula. Akan tetapi dalam pelaksanaan suatu rencana maka akan di temukan berbagai hambatan atau masalah yang di temui. Adanya supervisi yang dilakukan secara berkala dapat diketahui berbagai kendala dalam pelaksanaannya dan dapat diketahui pula kebutuhan apa yang mendukung proses keberhasilan pendidikan. Sehingga dari hasil kegiatan supervisi ini ada proses perbaikan secara tepat mengenai langkah apa yang harus diambil berdasarkan kendala yang dihadapi di sekolah. Oleh sebab, itu penulis tertarik ingin mengkaji dan melakukan penelitian mengenai kendala apa saja yang dihadapi dalam pelaksanaan supervisi selama masa pandemi Covid19 agar dapat dijadikan gambaran dan langkah preventif bagi sekolah lain utuk meminimalisir problematika dalam pelaksanaan supervisi.

Menurut Nurastati (2018:3) dalam pelaksanaan supervisi pendidikan di sekolah tentunya mengalami berbagai permasalahan yang muncul terutama kendala yang dihadapi oleh kepala sekolah selaku supervisor yang melaksanakan supervise di sekolah. Jika pada sebelum masa pademi Covid19 supervisi akademik sudah dideteksi akan memiliki permasalahan, apalagi dimasa masa pandemic seperti ini yang merupakan peristiwa yang baru terjadi di dunia pedidikan dan tentunya memiliki tantangan tersendiri jika dibandingkan dengan pelaksanaan supervisi sebelum adanya Covid-19. Oleh sebab itu disini penulis tertarik ingin mengkaji dan menganalisis kendala yang dihadapi oleh lembaga pendidikan dalam pelaksanaan supervisi akademik pada masa Pandemi Covid19.

Penelitian tentang analisis problematika pelaksanaan supervisi akademik pada masa pandemi Covid-19 di MI Islamiyah ini telah dilakukan oleh beberapa peneliti sebelumnya, yang pertama yakni penelitian yang dilakukan oleh Muhammad Munawir Pohan (2020) yang "berjudul Implementasi Supervisi Akademik Kepala Madrasah di Masa Pandemi Covid 19". Penelitian tersebut dilaksanakan di MTs Swasta PTP-VI Berangir Kecamatan $\mathrm{Na}$ IX-X Kabupaten Labuhanbatu Utara pada Tahun Ajaran 2020-2021. Penelitian ini bertujuan untuk mengetahui proses pelaksanaan supervisi pada masa pandemi Covid-19 melalui metode deskriptif kualitatif, yang mana fokus penelitian ini hanya untuk mengkaji bagaimana pelaksanaan supervisi pada masa pandemic Covid-19. Hasil penelitian ini menunjukan bahwa supervisi akademik yang dilaksanakan oleh kepala madrasah pada masa pandemi covid-19 berjalan normal dan berlangsung dengan baik karena MTsS PTP-VI Berangir termasuk zona hijau dan diperbolehkan melakukan tatap muka di kelas oleh tim gugus tugas covid 19 Kabupaten Labuhanbatu (Pohan, 2020). 
Kedua, terdapat pula penelitian yang dilakukan oleh Afif Takhlishi (2018) yang "Berjudul Implementasi Supervisi Pendidikan Pada Masa Pandemi Covid-19 Di Madrasah Aliyah Sunan Prawoto Pati". Penelitian in bertujuan untuk mendeteksi dan menyingkap kegiatan supervisi yang dilakukan oleh Kamad MA Sunan Prawoto dalam melihat kinerja guru pada masa pandemi Covid-19 dengan metode penelitian kualitatif. Fokus penelitian ini mengkaji pada supervisi akademik dan supervisi administrasi dalam pelaksanaan nya selama pandemic Covid-19. Hasil penelitian nya yakni ditemukan kendala dalam pelaksanaannya seperti a) aktivitas kegiatan Kamad yang sangat padat b) masih rendahnya kemampuan IT beberapa pendidik di MA Sunan Prawoto Pati, c) ketidaksiapan sarana dan prasarana madrasah yang menjadi sumber pendukung kegiatan PJJ (Takhlishi, 2018).

Penelitian selanjutnya atau yang ketiga yakni dari Fuldiaratman, Affan Malik, Minarni (2013) Program yang berjudul "Solusi Alternatif Permasalahan Pelaksanaan Supervisi Pendidikan Pada Mata Kuliah Pengelolaan Pendidikan Prodi Pendidikan Kimia”. Penelitian yang dilakukan oleh fuldiaratman dkk ini bertujuan untuk mengetahui permasalahan pelaksanaan supervisi serta langkah apasaja yang harus dilakukan untuk memecahkan permasalahan yang ditemukan dalam pelaksanaan supervisi serta memberikan tindak lanjut dari solusi yang sudah ditetapkan. Penelitian ini mengunakan pendekatan kualitatif. Hasil penelitian ini pun ditemukan permasalahan dalam pelaksanaan supervisi di mata kuliah pengelolaan pendidikan yang mana masalah tersebut bersumber dari pendidik, peserta didik dan fasilitas yang ada lemaga pendidikan nya (Fuldiaratman; Malik, 2013).

Dari ketiga penelitian diatas terlihat perbedaan aspek penelitian yang dilakukan oleh peneliti jika di bandingkan dengan tiga penelitian sebelumnya jika kita telaah yaitu terletak pada waktu pelaksanaan dan titik fokus penelitian yang dikajinya. Jika pada penelitian pertama dan kedua terdapat persamaan yakni waktu pelaksanaanya yang di lakukan pada masa pandemi tetapi objek yang dikaji atau dianalisis nya berbeda, penelitian pertama dan kedua mengkaji tentang pelaksanaan supervisi pada masa pandemi sedangkan penelitian yang di kaji oleh penulis ini fokus untuk menganalisa permasalahan yang ditemui pada pelaksanaan supervisi selama masa pandemi. Pada penelitian terdahulu yang ketiga meskipun terdapat persamaan dalam aspek yang dikaji mengenai permasalahan supervisi tapi terdapat perbedaannya yang terletak pada jenjang pendidikan dan waktu pelaksanaan supervisi yang dilakukan pada saat kondisi normal sebelum adanya Covid-19 yang mana keadaannya sangat berbeda dan mempunyai tantangan tersendiri dengan pelaksanaan pada masa pandemic Covid-19. Oleh sebab itu peneliti merasa perlu untuk melakukan penelitian ini untuk mendeteksi dan menemukan problematika yang ada dalam pelaksanaan supervisi akademik selama keadaan masa pandemic Covid- 
19 agar ditemukan solusi yang tepat dari permasalahan yang muncul dan dilakukan perbaikan secepatnya. Oleh karena itu peneliti mengangkat judul "Analisis Problematika Pelaksanaan Supervisi Dalam Proses Pembelajaran Pada Masa Pandemi Covid-19 di Mi Islamiyah Purwawinangun Cirebon."

Penelitian ini bertujuan untuk mengetahui kendala apa saja yang dihadapi dalam pelaksanaan supervisi akademik pada masa pandemic Covid19 yang merupakan peritiwa yang baru kita temukan dalam sejarah dunia pendidikan sehingga perlu diketahui hambatan atau masalah apa saja yang muncul dalam proses pelaksanaan nya agar ditemukan solusi yang tepat dari permasalahan yang muncul dan dilakukan perbaikan secepatnya. Hasil penelitian ini diharapkan bermanfaat bagi khasanah keilmuan yang bisa dijadikan gambaran bagi lembaga pendidikan ketika akan melaksanakan supervisi untuk mengetahui problematika yang sering mucul dan upaya yang bisa dilakukan untuk meminimalisirnya.

\section{B. METODE PENELITIAN}

Penelitian yang berjudul "analisis problematika pelaksanaan supervisi pendidikan pada masa pandemic Covid19" ini menggunakan jenis penelitian deskriptif kualitatif. Penelitian ini berupaya untuk memperoleh gambaran mengenai kendala dalam pelaksanaan supervisi pada masa pandemi di MI Islamiyah Cirebon. Makna penelitian kualitatif itu sendiri merupakan suatu metode dalam penelitian yang bisa digunakan untuk memahami keadaankeadaan yang bersumber dari masalah- masalah yang muncul dari aspek sosial atau kemanusiaan (Nugrahani, 2014).

Analisis yang digunakan dalam penelitian ini adalah deskriptif fenomenologis. Deskripsi fenomenologis yaitu mendeskripsikan temuan-temuan yang ditemukan di lapangan sebagai suatu hasil yang digunakan untuk mendapatkan gambaran yang objektif terkiat kasus yang menjadi pokok penelitian. Adapun jenis data yang digunakan dalam penelitian ini yakni terdiri dari data primer dan data sekunder. Data primer diperoleh dari data hasil wawancara dengan kepala sekolah dan guru. Sedangkan data sekunder berupa data yang diperoleh dari hasil studi literature, dokumentasi, dan beberapa jurnal artikel yang relevan dengan judul/kasus yang dikaji oleh peneliti. Proses pengumpulan data yang digunakan untuk pengumpulan data yang terdiri atas wawancara, dokumentasi serta studi pustaka. Peneliti menggunakan beberapa informan atau narasumber dari kepala sekolah dan guru untuk bisa membantu peneliti menemukan informasi untuk pemecahan masalah dari penelitian.

Untuk pemerolehan data secara komprehensif peneliti menggunakan triangulasi untuk mendukung kredibilitas maupun keabsahan data yang di peroleh. Dalam penelitian ini juga menggunakan member check untuk mendapatkan dan memperoleh data yang valid dan akurat. Data yang di peroleh peneliti dari informan akan dilakukan proses pengecekan ulang, yaitu dengan cara peneliti menanyakan kembali kepada informan apakah data yang peneliti tulis telah disepakati atau 
tidak, jika informan sepakat maka data tersebut telah valid dan dapat dipercaya. Hal tersebut dilakukan agar informasi yang diperoleh sesuai dengan apa yang dimaksud sumber data atau informan. Triangulasi dan member check yang dilakukan sampai menemukan data jenuh.

\section{LANDASAN TEORI}

\section{Supervisi Akademik}

Salah satu jenis supervisi yang dapat dilakukan oleh kepala sekolah dalam memberikan upaya perbaikan dan meningkatkan kualitas proses pembelajaran di kelas adalah dengan menggunakan supervisi akademik. Suliyarti (2013:2) mengartikan supervisi akademik sebagai rangkaian tahap kegiatan yang bertujuan untuk membantu guru selaku pendidik yang melakukan proses pembelajaran untuk dapat mengembangkan kemampuannya dalam melakukan proses pembelajaran untuk pencapaian tujuan pembelajaran. Pada hakikatnya kegiatan supervisi akademik yang dilakukan dan dijalankan oleh kepala sekolah selaku supervisor bertujuan untuk membimbing guru untuk meningkatkan kualitas pembelajarannya, sehingga pada akhirnya kualitas pembelajaran tersebut akan meningkatkan output atau prestasi belajar siswa yang dimiliki oleh siswa. Hal ini sejalan dengan yang disampaikan oleh Yusuf (2017:136), kegiatan supervisi yang dilakukan memiliki tujuan untuk perbaikan guru dalam kemampuan mengajarnya di kelas dan juga sebagai upaya yang dilakukan oleh kepala sekolah untuk mengembangkan kompetensi guru dalam menyampaikan ilmu kepada siswa di kelas.

Evanofrita et al., (2020:225) menjelaskan bahwa supervisi akademik pada asalnya adalah hubungan yang terjalin antara manusia dengan manusia yang lain yang saling berinteraksi positif dalam upaya perbaikan. Supervisi akademik merupakan interaksi antara kepala sekolah dengan guru.

Menurut Suliyarti (2013:2), Supervisi akademik yang dilakukan oleh kepala sekolah meliputi beberapa tahap, yaitu :

a) Supervisi akademik pada perencanaan pembelajaran

Dalam aspek perencanaan yakni dilakukan penetapan suatu kegiatan/pekerjaan yang harus di implementasikan oleh suatu kelompok atau individu untuk mencapai tujuan yang digariskan atau yang telah ditetapkan sebelumnya

b) Supervisi akademik pada pelaksanaan pembelajaran

Inti dari proses berjalan nya kegiatan pendidikan di sekolah terletak pada pelaksanaan pembelajaran yang dilakukan, yang mana dalam aspek ini terjadi interaksi antara guru dan siswa dalam mentrasnfer ilmu untuk mencapai target tujuan pembelajaran

c) Supervisi akademik pada evaluasi pembelajaran

Aspek terakhir dalam kegiatan supervise akademik 
yakni dilakukan evaluasi atau penilaian hasil belajar yang bertujuan untuk mengukur kemajuan belajar siswa dalam hal penguasaan kognitif, afektif dan psikomotorik nya.

Dalam aktivitas implementasi supervisi nya memiliki berbagai problematika yang dihadapi dan harus segera ditemukan solusinya oleh para supervisor, terutama daru pihak pemerintah yang memiliki tanggung jawab dan wewenang untuk mengatasinya demi terwujudnya iklim supervisi yang baik dan efektif yang pada akhirnya hal tersebut memiliki dampak positif terhadap peningkatan mutu pendidikan nasional (Nurmayuli, 2018:83).

\section{Pandemi Covid-19}

Coronavirus itu sendiri adalah keluarga besar virus yang menyebabkan penyakit mulai dari gejala ringan sampai berat (Aji et al., 2020:56). Kementerian Pendidikan dan Kebudayaan (Kemendikbud) mulai mengimplementasikan upayaupaya awal untuk mencegah penyebaran Covid-19 di sekolahsekolah dengan mengeluarkan Surat Edaran Nomor 3 Tahun 2020 yang secara garis besar menyarankan praktik higienitas dan sanitasi di sekolah-sekolah (Azzahra, 2020). Surat Edaran Nomor 3 Tahun 2020 tentang Pencegahan Covid-19 pada Satuan Pendidikan. SE ini dikeluarkan pada tanggal yang sama dengan SE nomor 2 tahun 2020 yakni pada tanggal 09 maret 2020 . SE nomor 3 tahun 2020 ini memuat himbauan dari kemendikbud terkait pengarahan dalam pelaksanaan kegiatan pendidikan dimasa pandemi disatuan pendidikan

Adanya pandemi covid-19 yang memasuki Indonesia membawa dampak yang sangat signifikan dalam seluruh lapisan kehidupan, salah satu yang menjadi dampaknya yaitu dengan dikeluarkannya kebijakan pendidikan yang berlaku di Indonesia. Kebijakan belajar online atau dalam jaringan (daring) yang diambil oleh pemerintah menjadi kebijakan prioritas yang wajib dan harus dilaksanakan oleh seluruh lembaga sekolah di Indonesia.

Salah satu langkah yang sangat efektif dan strategis yang diambil oleh pemerintah dalam mencegah rantai penyebaran Covid-19 yang semakin membludak dan meluas yakni dengan menghadirkan pembelajaran jarak jauh (PJJ) atau $e$ learning dengan mengandalkan bantuan media teknologi sebagai alat dalam proses pelaksanaannya. Proses pelaksanaan pembelajaran biasanya menggunakan perangkat software berupa aplikasi pembelajaran online yang bisa dimanfaatkan untuk live meeting mapun interaksi pemebelajaran seperti aplikasi admodo, google classroom, zoom, whatsapp dan lain sebagainya.

Covid-19 berdampak besar pada seluruh sektor termasuk lembaga pendidikan yang ikut terkena dampaknya. Menurut data yang dilansir oleh Organisasi 
Pendidikan, Keilmuan, dan Kebudayaan PBB, menyatakan bahwa setidaknya ada 290,5 juta peserta didik diseluruh dunia yang terkena dampak pendidikan akibatnya aktivitas pembelajaranpun menjadi terganggu akibat adanya Covid-19 (Wiryanto, 2020). Data dari UNESCO menyebutkan bahwa pada tanggal 17 April 2020 siswa dibelahan dunia yang tidak dapat melaksanakan kegiatan pembelajaran sebagai dampak dari adanya wabah Covid-19 ini ada 1.5 miliar atau jika dilihat dari jumlah presentase ada 91,3\%. Dari jumlah data yang disebutkan oleh UNESCO, Indonesia berada pada presentase $3 \%$ atau kurang lebih 45 juta siswa dari jumlah secara menyeluruh yang terkena dampuak dibelahan dunia (Badan Pusat Statistik, 2020).

Adanya Covid-19 selain mengancam kesehatan manusia juga yang menjadi alasan dilaksanakan pembelajaran secara online diseluruh belahan dunia. Guru sebagai elemen yang sangat krusial dan sangat penting sekali dalam aktivitas pengajaran dituntut melakukan migrasi dari yang sebelumnya pembelajaran dilakukan secara tatap muka tradisional ke pendidikan online atau pendidikan jarak jauh (Herliandry et al., 2020:65).

\section{Problematika pelaksanaan supervisi di masa pandemi}

Ada berbagai problematika yang dihadapi ketika pelaksanaan supervisi, sebagaimana yang disampaikan oleh (Pohan, 2020:196) terdapat problem yang terjadi ketika kepala sekolah melakukan supervisi, yakni kepala sekolah hanya melakukan tugasnya dengan mengukur kinerja guru dari instrument penilaian kerja. Sedangkan kegiatan supervisi tidak memberi pengaruh yang signifikan bagi perbaikan kualitas guru jika dilakukan seperti itu.

Kebijakan pendidikan

mengalami beberapa perubahan dalam proses pelaksanaannya. Wabah pandemic Covid-19 yang mengancam kesehatan para siswa tapi disisi lain pemerintah juga ingin mempertahankan aktivitas pendidikan agar siswa tetap mendapatkan asupan ilmu disaat wabah Covid-19 ini. Oleh sebab itu diberlakukanlah kebijakan baru di dunia pendidikan yang mengharuskan siswa belajar dengan sistem jarak jauh atau yang dikenal dengan PJJ online. Terkait pelaksanaan kebijakan pandemi covid-19 yang telah diberlakukan dan diterapkan terhitung dari bulan maret hingga sekarang tentunya ada berbagai tantangan yang dihadapi oleh guru dan siswa selaku pelaksana dalam kebijakan tersebut, termasuk dalam pelaksanaan supervisi akademik tentunya mengalami problem dan kesulitan.

Problematika pembelajaran Daring ini dirasakan oleh semua pihak tidak hanya dialami oleh murid-murid, tetapi juga guru-guru yang mempunyai tantangan tersendiri dalam membuat soal ujian yang berbeda dari sebelumnya yaitu pembuatan soal yang diharuskan dalam bentuk google form, sehingga hal ini merupakan sesuatu hal yang 
baru bagi guru-guru di Indonesia. Salah satu faktor yang menjadi alasan kenapa pembelajaran daring memunculkan segudang problematika yang ditemukan selama proses pelaksanaan nya karena ditengah pandemi banyak orang menjadi korban dan merasakan dampak kesulitan karena Covid-19 seperti terjadi Pemutusan Hubungan Kerja (PHK) besarbesaran, kantin sekolah tidak jalan karena belajar tidak dilakukan secara tatap muka, transportasi lumpuh tidak beroperasi, pedagang sepi konsumen, masyarakat disuruh menahan diri di rumah, menjaga imun tubuh dan ibadah serta kerja dari rumah. Sementara dengan adanya kebijakan tersebut menambah biaya pengeluaran rumah tangga.

Usaha pemerintah dalam memaksimalkan kebijakan pembelajaran daring ini terus digalakan dan dilakukan seperti pemberian paket internet kepada guru-guru dan siswa secara Cumacuma untuk dapat mengikuti pembelajaran daring dengan lancer tanpa mengalami hambatan.

\section{PEMBAHASAN DAN HASIL}

\section{Profil Madrasah Ibtidaiyyah Islamiyyah}

MI Islamiyah Purwawinangun merupakan sekolah yang berada dibawah naungan Yayasan Pendidikan Islam Wilayatullah yang di dirikan pada 01 Juli 1950 yang memiliki No. SK Izin Operasional 1.02.11.21.164. MI Islamiyah sendiri berada di daerah Jalan Sunan
Gunung Jati Desa Purwawinangun Kecamatan Suranengala Kabupaten Cirebon yang sudah terakreditasi "B" dengan nomor NSM/NPSM 111232090118/60708693.

MI Islamiyah yang dipimpin oleh seorang kepala sekolah bernama Hj. Aliyah, S.Pd.I merupakan satu diantara tiga sekolah yang berada dibawah naungan Yayasan Pendidikan Islam Wilayatullah yang memiliki 3 jenjang sekolah yakni : sekolah ditingkat dasar bernama MI Islamiyah Purwawinangun, ditingkat sekolah Menengah bernama MTs Tsanawiyah dan ditingkat sekolah menengah atas dinamakan MA Kapetakan.

\section{Problematika Pelaksanaan Supervisi Akademik pada Masa Pandemi Covid-19}

Berdasarkan hasil wawancara dengan kepala sekolah selaku subjek yang menjalankan kegiatan supervisi di sekolah dan didukung oleh pernyataan dari guru senior yang menjadi penguat argument, diperoleh data informasi terkait problematika supervisi yang dialami selama masa pandemi Covid-19, yakni sebagai berikut:

a) Supervisi Akademik Pada Perencanaan Pembelajaran

Idealnya dalam proses perencanaan supervisi akademik yang termaktub dalam Permendiknas nomor 41 tahun 2007 dijelaskan bahwa perencanaan pembelajaran meliputi penyusunan silabus dan rencana pelaksanaan pembelajaran (RPP) yang 
berpijak pada kurikulum yang berlaku. Akan tetapi setelah adanya wabah pandemi Covid ini pelaksanaan supervisi di MI Islamiyah menemukan kendala dalam aspek perencanaanya tidak bisa berjalan seperti yang diamanatkan oleh Kemendiknas No 41 tahun 2007.

Untuk proses perencanaan RPP dan silabus dalam penerapan nya masih bisa diatasi oleh para guru meskipun dalam kondisi pandemi Covid-19, sebagaimana yang disampaikan oleh Kepala Madrasah ibu Hj. Aliyah, S.Pd.I yang mengatakan bahwa: "Tugas administrasi guru dalam hal RPP dan silabus masih bisa terlaksana dengan baik meskipun terdapat perbedaan dengan RPP sebelumnya, RPP yang sekarang guru menggunakan RPP darurat Covid sehingga bisa menyesuaikan dengan pembelajaran yang sedang di lakukan secara online. Meskipun demikian hal itu bukan menjadi salah satu kendala yang ditemui dari hasil pelaksanaan supervisi”.

Terkait aspek perencanaan dalam hal administratif guru mengenai RPP dan Silabus masih bisa dilaksanakan akan tetapi terdapat problem lain yang ditemui kepala sekolah dalam hal yang terkait dengan administratif yakni mengenai kurikulum yang menjadi salah satu faktor problematika yang muncul ketika pelaksanaan supervisi. b) Supervisi Akademik Pada Pelaksanaan Pembelajaran

Dalam pelaksanaan nya mengalami perubahan yang drastis dari pembelajaran tatap muka menjadi pembelajaran daring, hal ini merupakan peristiwa pertama kali sepanjang sejarah pendidikan di Indonesia. Ada perbedaan proses pegajaran yang tentunya memiliki tantangan tersendiri yang dihadapi oleh para guru yang ada di MI Islamiyah Cirebon. Tantangan tersebut juga yang menjadi problem yang ditemukan ketika pelaksanaan supervisi. Sebagaimana yang disampaikan oleh kepala sekolah yakni yang mengatakan: "hasil kegiatan supervisi sebelumnya ditemukan kendala ketidaksiapan guru dalam melangsungkan pembelajaran online. Guru masih kebingungan karna pembelajaran online akibat pandemi Covid-19 ini begitu mendadak sedangkan para guru belum mendapatkan pelatihan dalam proses pelaksanaan daring dan belum mempunyai pengalaman terkait pembelajaran online sehing ga hal ini mengalami kendala dan kesulitan dalam pelaksanaan pembelajaran nya"

Kurang siapnya guru dalam melaksanakan pembelajaran ditengah pandemic mengingat kondisi yang mendadak ini menjadi tantangan tersendiri bagi guru dalam menyiapkan dan melaksanakan pembelajaran yang tidak seperti biasanya. 
Hal tersebut diperkuat oleh pernyataan seorang informan (guru) senior yang mengatakan bahwa: "para guru disini kesulitan dalam melaksanakan proses pembelajaran yang serba terbatas ini apalagi masih terdapat guru yang belum menguasai dunia teknologi yang kini di jadikan sebagai media utama dalam proses pembelajaran. Kesiapan para guru selaku fasilitator pembelajaran yang masih belum begitu faham dengan penggunaan teknologi cara memanfaatkan nya sebagai media pembelajaran"

Berdasarkan penuturan yang di sampaikan oleh kepala sekolah dan guru senior yang ada di MI Islamiyah dapat diketahui bahwa problematika supervisi yang ditemukan dalam proses pelaksanaan pembelajaran yakni aktivitas pembelajaran belum bisa berjalan secara optimal karena ketidaksiapan guru yang masih kebingungan dalam menyiapkan pelaksanaan pembelajaran berbasis IT serta tidak ada regulasi dari pemerintah secara khusus mengenai teknis pelaksanaan kegiatan pembelajaran yang serentak dilaksanakan di Indonesia. Dampak dari ketidaksiapan guru dalam melaksanakan pembelajaran online akan berpengaruh terhadap hasil belajar peserta didik yang tidak maksimal.

Pelaksanaan pembelajaran dimasa pandemi covid 19 berjalan kurang optimal disebabkan keterbatasan jam efektif mengajar. Hal itu terjadi karena sistem pembelajaran yang diterapkan berupa tatap muka secara bergiliran/bergantian tiap kelasnya dalam satu minggu (Pohan, 2020:197).

Muhaiminah Jalal (2020:36) menyatakan bahwa kesiapan guru dalam mengelola pembelajaran menjadi hal yang sangat penting sekali dalam keberhasilan pembelajan yang dilakukan oleh guru. Senada dengan yang disampaikan oleh Muhammad jalal, Suhartono dalam Muhdi dan Nurkolis (2021:223) menjelaskan bahwa belum ada standar $e$ learning yang diatur oleh pemerintah Indonesia sehingga pemanfaatan dalam media tekhnologi dan situs e-learning masih dikatakan kurang dan kualitas yang dihasilkan dari pembelajaran menggunakan media $e$-learning kurang efektif dan masih rendah dan ketersediaan internet di Indonesia juga masih rendah

Kepala sekolah juga menambahkan terkait informasi mengenai problem yang ditemukan dilapangan dari hasil kegiatan supervisi yang telah dilakukan nya berupa sikap protes dari orangtua murid terkait pelaksanaan kegiatan belajar online karena melihat ada sekolah lain yang belajar tatap muka sedangkan di MI Islamiyah tidak diadakan tatap muka sebagaimana penuturan yang disampaikan 
kepala sekolah yakni: "Setiap sekolah memiliki perbedaan teknis pelaksanaan pembelajaran nya sehingga menyebabkan orangtua murid protes menginginkan adanya pembelajaran tatap muka membanding-bandingkan dengan teknis pembelajaran di sekolah lain, hal itu terjadi karena melihat ada sekolah lain yang melaksanakan kegiatan tatap muka seminggu 2x. Teknis pembelajaran tiap sekolah yang tidak serentak ini menimbulkan perdebatan diantara orangtua murid. Melihat dari kasus tersebut sekolah memerlukan adanya regulasi khusus yang dibuat oleh menteri pendidikan terkait teknis pelaksanaan proses kegiatan pembelajaran online, karna selama ini tidak ada aturan khusus bagaimana pedoman pembelajaran selama covid-19 dari Kemendikbud."

Hal tersebut juga disampaikan oleh guru senior yang menyampaikan bahwa: "pemerintah juga tidak menetapkan aturan secara khusus bagaimana teknis pelaksanaan pembelajaran nya, semuanya diserahkan kepada sekolahnya dan guru nya masing sehingga guru kesulitan menyusun rencana pembelajaran nya karena belum ada pengalaman dalam hal ini”. Penuturan yang disampaikan oleh kepala sekolah guru tersebut senada dengan yang disampaikan oleh Dwi et al
(2020:36) yang menyatakan bahwa sistem merdeka belajar yang digaungkan oleh menteri pendidikan tidak ada acuan atau pedoman dalam pelaksanaannya sehingga membuat tenaga pendidik kebingungan melaksanakan PJJ dengan baik.

Dalam pelaksanaan supervisi kepala sekolah merapatkan terlebih dahulu, sebagaimana yang sampaikan oleh kepala sekolah yakni: "supervisi dilakukan $3 x$ dalam satu semester, jadwal ketika akan melakukan supervisi sudah diketahui bersama ketika diadakan rapat dengan para guru."

Sebagaimana yang disampaikan oleh (Novianti, 2015) menyatakan bahwa kepala sekolah ketika penyusunan program supervisi akademik perlu melibatkan guru ketika akan menentukan jadwal kunjungan kelas.

c) Supervisi Akademik Pada Penilaian Hasil Belajar

1) banyak siswa yang tidak faham tentang materi pembelajaran

Daya tangkap siswa dalam memahami materi pelajaran saat belajar daring tentunya berbeda dengan pembelajaran tatap muka, hal ini ditemukan dari hasil supervisi yang dilakukan oleh kepala sekolah MI Islamiyah, Sebagaimana penuturannya yakni: "ketika dilakukan supervisi ternyata daya tangkap siswa dalam 
memahami pelajaran masih rendah selama pembelajaran daring ini, melihat dari aspek penilaian hasil belajar siswa ketika penugasan maupun ulangan yang mayoritas mendapatkan nilai rendah khususnya di pelajaran matematika dan dari penyampaian orang tua murid yang mengaku anak nya kesulitan dalam belajar di rumah yang membuat hasil belajar siswa kurang maksimal jika dibandingkan dengan sebelum adanya Covid-19"

Dari pernyataan kepala sekolah diperoleh informasi terkait problem yang dialami guru dan siswa dari hasil pembelajaran yang berlangsung bahwa adanya kebijakan ini guru dan peserta didik dalam hal pembelajaran nya tidak memberikan stimuls atau respon yang baik dalam pemahaman materi pelajaran yang disampaikan oleh guru sehingga hal tersebut tidak dapat memberi feedback secara cepat dalam aspek muatan pelajarannya, pemahaman anak terhaap suatu materi kurang mendalam meskipun sudah dijelaskan akan tetapi hasil daya tangkapnya akan berbeda ketika penyampainan materi pelajaran disampaikan secara langsung didalam kelas oleh guru.

Pemahaman siswa akan penerimaan konsep dan materi pelajaran yang dijelaskan dan disampaikan oleh guru melalui pembelajaran online tidak bisa diserap secara maksimal oleh siswa meskipun dalam hal ini guru sudah memanfaatkan sumber media pembelajaran yang beragam .(Dwi et al., 2020)

2) Guru tidak bisa menerapkan penilaian secara menyeluruh (kognitif, afektif dan psikomotorik)

Dalam aspek penilaian guru tidak dapat menilai keseluruhan proses belajar siswa. Guru hanya bisa memberi nilai siswa melalui hasil kerja yang dikumpulkan saja. Sebagaimana yang disampaikan oleh kepala sekolah yakni: "ada kendala dalam proses penilaian peserta didik khususnya di aspek penilaian afektif, karena pembelajaran secara online jadi penilaian afektif sulit untuk di nilai"

Hal ini diperkuat oleh statement dari pak Sholeh selaku guru yang mengajar siswa kelas 4 yang menyatakan bahwa: "tidak bisa melihat perkembangan belajar, karakter, dan perkembangan kemampuan kognitif terutama, karna kita ga bisa ngontrol langsung dan untuk penilaian sikap siswa sulit karna kita ga berinteraksi langsung dengan siswa"

Mendengar dari penyataan kepala sekolah dan guru dari hasil wawancara 
tersebut diperoleh informasi bahwa dalam hal ini guru tidak bisa menilai siswa dari aspek afektif. Dari segi aspek penilaian nya guru hanya melakukan penilaian hasil nya saja (kognitif dan psikomotorik) untuk penilaian afektif dalam kebijakan pandemi Covid-19 ini sulit untuk diterapkan.

\section{Upaya Mengatasi Problem yang Muncul dalam Pelaksanaan Supervisi pada Masa Pandemi Covid-19}

Dari hasil supervisi akademik yang telah dilakukan selama masa pandemic covid-19 ini terdapat beberapa problematika yang muncul, sehingga perlu adanya upaya untuk mengatasi dan meminimalisir setiap masalah. Pelaksanaan supervisi akademik yang telah dilakukan diharapkan dapat memperbaiki kemampuan mengajar guru dan dapat meningkatkan kinerja guru dalam pembelajaran yang efektif. Adapun upaya dari pihak sekolah dalam mengatasi masalah yang muncul dari hasil pelaksanaan supervisi yaitu :

a) Supervisi Akademik Pada Perencanaan Pembelajaran

Problem yang muncul dari perencanaan materi ajar yang ada pada kurikulum nasional tidak bisa dilakukan secara menyeluruh dan mentuntaskan isi kurikulum dalam kondisi pandemi sehingga upaya dari pihak kepala sekolah menyiasati dengan mengganti kurikulum nasional dengan kurikulum darurat Covid-19.

Dari hasil kegiatan supervisi yang telah dilakukan oleh kepala sekolah untuk aspek pelaksanaan kurikulum mengalami kendala karena ditengah kondisi pandemi seperti ini karena karena beban kurikulum materi ajar yang harus dituntaskan sangat banyak jika harus dilakukan pada saat pandemi seperti ini sehingga sulit dalam melaksanakan dan mentuntaskan isi kurikulum yang telah ditetapkan oleh pemerintah dengan kondisi pandemi seperti ini.

Sebagaimana penuturan yang disampaikan oleh kepala sekolah yakni: "awalnya sekolah menggunakan kurikulum nasional ketika awal pembelajaran daring tapi setelah dilakukan supervisi ternyata mengalami banyak kendala dalam pelaksanaan kurikulum nasional tidak bisa dilakukan secara menyeluruh karena ada beberapa yang sulit diterapkan dalam kondisi pandemic Covid-19 sehingga kita ganti menggunakan kurikulum darurat yang telah disiapkan oleh kemendikbud sebagai gantinya"

Dari hasil pemaparan yang disampaikan oleh kepala sekolah diperoleh informasi bahwasanya ketika pelaksanaan supervisi kepala sekolah mengalami problem ketika menggunakan kurikulum nasional sebagai acuan ketika pembelajaran daring selama covid-19, setelah ditemui problem dalam pelaksanaan nya 
$\begin{array}{lrr}\text { kepala sekolah } & \text { mengganti } \\ \text { kurikulum } & \text { dengan } & \text { kurikulum } \\ \text { darurat. } & & \end{array}$ Dalam hal ini pemerintah memang memberikan kelonggaran kepada setiap lembaga pendidikan untuk memilih kurikulum sesuai kemampuan masing-masing sekolah. Sesuai yang dilansir dari halaman artikel kemendikbud.go.id bahwa sekolah bebas memilih satu diantara 3 kurikulum yakni: (1) tetap berpedoman pada Kurikulum Nasional (2) dapat menggunakan atau mengacu pada kurikulum darurat; atau (3) melakukan penyederhanaan kurikulum secara mandiri oleh sekolah masing-masing. Kemendikbud memberikan kesempatan bagi semua jenjang pendidikan pada kondisi khusus dapat memilih dari tiga opsi kurikulum tersebut

b) Supervisi Akademik Pada Pelaksanaan Pembelajaran

1) Faktor ketidaksiapan guru dalam mengajar karena keterbatasan pengetahuan dalam pemanfaatan teknologi telah diberikan bimbingan dan arahan oleh kepala sekolah dalam sebuah rapat dan memfasilitasi guru untuk mengikuti pelatihan untuk meningkatkan kompetensi melalui pembelajaran secara online dengan menggunakan aplikasi ruang guru. Dalam hal ini guru harus beradaptasi dengan keadaan pandemi yang sedang terjadi dan pendidik dituntut untuk merespon sikap dan tindakan untuk mau belajar hal-hal baru. Pemanfaatan teknologi harus menjadi acuan bagi guru untuk mampu menghadirkan proses pembelajaran yang efektif. sebagaimana yang disampaikan oleh kepala sekolah yang menyatakan bahwa: "untuk mengatasi kendala yang ditemukan terkait beberapa guru yang belum memahami pemanfaatan teknologi sebagai media pembelajaran, saya memberikan bimbingan dan arahan kepada guru untuk mengikuti ruang guru sebagai upaya peningkatan kompetensi guru untuk mengikuti perkembangan zaman agar tidak kesulitan dalam menerapkan kegiatan pembelajaran daring"

2) Teknis Pelaksanaan pembelajaran menuai kontra dari pihak orangtua siswa yang menginginkan belajar tatap muka seperti sekolah lain. Teknis pembelajaran tiap sekolah yang tidak serentak ini menimbulkan perdebatan diantara orangtua murid. Sehingga dalam hal ini kepala sekolah mengambil keputusan untuk diselenggarakan pembelajaran tatap muka seperti yang dinginkan oleh orangtua murid sebanyak $2 x$ dalam seminggu dengan tetap mematuhi dan mengikuti 
protokol kesehatan yang berlaku. Sebagaimana yang disampaikan oleh kepala sekolah yang menuturkan: "langkah solutif yang kami lakukan untuk menghindari suasana yang semakin keruh yakni dilakukan pembelajaran tatap muka yang dilaksanakan sebanyak $2 x$ dalam satu minggu dari yang semula dilakukan hanya $1 x$ dalam satu minggu."

c) Supervisi Akademik Pada Penilaian Hasil Belajar

Hasil belajar siswa yang kurang memuaskan dan pemahaman siswa tentang materi pelajaran yang masih minim selama daring ditindaklajuti dengan arahan kepala sekolah kepada guru untuk memaksimalkan penjelasan materi pelajaran ketika pembelajaran tatap muka berlangsung dan menambahkan jadwal 2x pembelajaran tatap muka dalam seminggu dari awalnya hanya $1 \mathrm{x}$ dalam seminggu. Sebagaimana yang disampaikan oleh kepala sekolah yang menuturkan bahwa: "saya menghimbau kepada para guru yang ada disini untuk memaksimalkan peran guru dalam menjelaskan materi pelajaran ketika pembelajaran tatap muka terutama pada mata pelajaran matematika yang memerlukan bimbingan dan penjelasan secara lebih khusus yang disampaikan oleh guru dikelas"

\section{E. SIMPULAN DAN SARAN}

1. Simpulan

Dari hasil penelitian yang telah dilakukan terkait problematika dalam pelaksanaan supervisi akademik di MI Islamiyah selama masa pandemic Covid-19 ini sangat beragam sekali. Dari 3 aspek proses supervisi akademik (perencanaan, pelaksanaan dan penilaian hasil belajar) yang telah dilaksanakan di MI Islamiyah Purwawinangun diperoleh problem yang berbeda dari setiap aspeknya dan bersumber dari berbagai pihak seperti: (a) problematika supervisi dalam aspek perencanaan pembelajaran : dalam perencanaan RPP dan silabus tidak mengalami kendala hanya saja beban materi bahan ajar yang terdapat pada kurikulum nasional terlalu banyak jika diterapkan pada masa pandemi covid-19, sehingga sulit untuk direalisasikan secara menyeluruh; (b) problematika pelaksanaan supervisi pada pelaksaan pembelajaran diantaranya, kurangnya persiapan dari pendidik yang disupervisi dalam melaksanakan pembelajaran daring, masih kurangnya pengetahuan pendidik tentang cara memanfaatkan media teknologi sebagai media pembelajaran yang efektif, masih terdapat guru yang gaptek akan teknologi; (c) problematika pelaksanaan supervisi penilaian pembelajaran : aspek penilaian afektif dalam pembelajaran daring kurang maksimal karena keterbatasan jarak dan pembelajaran yang dilakukan secara daring, perbedaan daya serap peserta didik dalam memahami materi pelajaran. 
Setelah diketahui problematika supervisi akademik yang muncul, upaya yang dilakukan oleh kepala sekolah selaku pihak yang bertanggung jawab dalam penyelenggaraan pendidikan yaitu: pemberian bimbingan dan arahan terkait pemanfaatan teknologi sebagai media pembelajaran utama ketika daring, keputusan kepala sekolah terkait pelaksanaan pembelajaran tatap muka sebanyak $3 \mathrm{x}$ dalam seminggu, dan pergantian kurikulum nasional dengan kurikulum darurat Covid-19 untuk memudahkan guru dalam menyesuaikan materi pembelajaran pada saat pandemi Covid-19. Dengan dilaksanakan supervisi dapat memberikan bantuan dan terobosan solutif terhadap permasalahan dalam pelaksanaan pendidikan dan kesulitan para guru pada sehingga dapat memperbaiki kinerja dan proses pembelajarannya, sehingga tujuan pendidikan dapat dicapai secara efisien.

2. Saran

a) Bagi sekolah

Pihak sekolah harus terus melaksanakan supervisi akademik secara rutin dan terjadwal selama masa pandemi ini, karena masa pembelajarn selama pandemi ini penuh tantangan dan merupakan sebuah hal yang baru terjadi didunia pendidikan sehingga perlu diadakan supervisi secara rutin guna mendeteksi sekecil apapun masalah yang muncul selama proses pembelajaan daring agar dapat ditanggualangi segala permasalahan yang muncul. Oleh sebab itu dengan dilaksanakan supervisi diharapkan dapat memberikan bantuan dan terobosan solutif terhadap permasalahan pendidikan pada umumnya dan para guru pada khususnya agar dapat memperbaiki kinerja dan proses pembelajarannya, sehingga tujuan pendidikan dapat dicapai secara efisien.

b) Bagi pemerintah

Perlu adanya regulasi khusus yang dibuat oleh menteri pendidikan terkait teknis pelaksanaan kegiatan pembelajaran online, karna selama ini tidak ada aturan khusus bagaimana pedoman pembelajaran selama covid-19 dari Kemendikbud. Sistem merdeka belajar yang digaungkan oleh menteri pendidikan tidak ada acuan atau pedoman dalam pelaksanaannya sehingga membuat tenaga pendidik kebingungan melaksanakan PJJ dengan baik. Dan hal ini juga menimbulkan reaksi orangtua murid yang banyak menuai protes

c) Bagi penulis

Hasil penelitian ini masih jauh dari kata sempurna sehingga penulis sangat membutuhkan saran dari semua pihak demi berkembangnya ilmu permasalahan supervisi pada masa pandemi agar lebih kompleks khasanah keilmuan nya. 


\section{DAFTAR PUSTAKA}

Aji, W., Dewi, F., Kristen, U., \& Wacana, S. (2020). Dampak Covid-19 Terhadap Implementasi Pembelajaran Daring di Sekolah Dasar. Edukatif Jurnal Ilmu Pendidikan. 2(1), 55-61.

Alpian, Y., Anggraeni, S. W., Wiharti, U., \& Soleha, N. (2019). Pentingnya Pendidikan Bagi Manusia. Jurnal Buana Pengabdian, 1 (1, 66-72.

Anugrahana, A. (2020). Hambatan, Solusi dan Harapan: Pembelajaran Daring Selama Masa Pandemi Covid-19 Oleh Guru Sekolah Dasar. Scholaria: Jurnal Pendidikan Dan Kebudayaan, 10(3), 282-289.

Azzahra, N. F. (2020). Mengkaji Hambatan Pembelajaran Jarak Jauh di Indonesia di Masa Pandemi Covid19. Center for Indonesians Policy Studies, 19(2), 1-9. https://id.cipsindonesia.org/post/mengkajihambatan-pembelajaran-jarak-jauhdiindonesia-di-masa-covid-19

Dwi, B., Amelia, A., Hasanah, U., \& Putra, A. M. (2020). Analisis Keefektifan Pembelajaran Online di Masa Pandemi Covid-19. Jurnal Pendidikan Guru Sekolah Dasar, 2(1), 28-37.

Evanofrita, Rifma, \& Nellitawati. (2020). Pelaksanaan Supervisi Akademik Kepala Sekolah Di Sekolah Luar Biasa. JMKSP (Jurnal Manajemen, Kepemimpinan, Dan Supervisi Pendidikan), 5(2), 217-229.

Fuldiaratman; Malik, A. M. (2013). Solusi Alternatif Permasalahan Pelaksanaan Supervisi Pendidikan Pada Mata Kuliah Pengelolaan Pendidikan Prodi Pendidikan Kimia. Journal of the Indonesian Society of Integrated Chemistry, 11(1) 19-27.

Herliandry, L. D., Nurhasanah, Suban, M. E., \& Heru, K. (2020). Pembelajaran Pada Masa Pandemi Covid-19. Jurnal Teknologi Pendidikan, 22(1), 65-70. http://journal.unj.ac.id/unj/index.php/j tp
Muhaiminah Jalal. (2020). Kesiapan Guru Menghadapi Pembelajaran Jarak Jauh Di Masa Covid-19. SMART KIDS: Jurnal Pendidikan Islam Anak Usia Dini, 2(1), 35-40. https://doi.org/10.30631/smartkids.v2 i1.61

Muhdi dan Nurkolis. (2021). Keefektivan Kebijakan E-Learning berbasis Sosial Media pada PAUD di Masa Pandemi Covid-19. Jurnal Obsesi: Jurnal Pendidikan Anak Usia Dini, 5(1), 212-228.

https://doi.org/10.31004/obsesi.v5i1.5 35

Novianti, H. (2015). Pelaksanaan Supervisi Akademik Kepala Sekolah Dalam Meningkatkan Kinerja Guru. Manajer Pendidikan, 9(2), 350-358.

Nugrahani, F. (2014). Metode Penelitian Kualitatif dalam Penelitian Pendidikan Bahasa (1st ed., Vol. 1, Issue 1). cakra books. http://ejournal.usd.ac.id/index.php/LLT\%0A http://jurnal.untan.ac.id/index.php/jpd pb/article/viewFile/11345/10753\%0A http://dx.doi.org/10.1016/j.sbspro.201 5.04.758\%0Awww.iosrjournals.org

Nurastati. (2018). Kondisi Supervisi Pendidikan Yang Seharusnya Terjadi. Journal of Materials Processing Technology, 1(1), 1-8. http://dx.doi.org/10.1016/j.cirp.2016. 06.001\%0Ahttp://dx.doi.org/10.1016/ j.powtec.2016.12.055\%0Ahttps://doi. org/10.1016/j.ijfatigue.2019.02.006\% 0Ahttps://doi.org/10.1016/j.matlet.20 19.04.024\%0Ahttps://doi.org/10.1016 /j.matlet.2019.127252\%0Ahttp://dx.d oi.o

Nurmayuli. (2018). Realita, Problematika Dan Harapan Dalam Supervisi Pendidikan. Jurnal Penelitian Sosial Agama, 3(1), 59-85.

Pohan, M. M. (2020). Implementasi Supervisi Akademik Kepala Madrasah di Masa Pandemi Covid 19. Jurnal Pendidikan Dan Kependidikan, 4(2), 195-208.

Suliyarti, R. (2013). Supervisi Akademik 
Kepala Sekolah Untuk Meningkatkan

Proses Pembelajaran. Journal of Chemical Information and Modeling, 53(9), 1689-1699.

Takhlishi, A. (2018). Covid-19 Di Madrasah Aliyah Sunan Prawoto Pati Covid-19 Pandemic At Madrasah Aliyah Sunan Prawoto. Jurnal Intelegensia, 06(1), 72-85.

Wiryanto. (2020). Proses Pembelajaran Matematika Di Sekolah Dasar Di Tengah Pandemi Covid-19. Jurnal Review Pendidikan Dasar: Jurnal Kajian Pendidikan dan Hasil Penelitian, 6(2), 125-132.

Yusuf, M. (2017). Pelaksanaan Supervisi Akademik Oleh Kepala Sma Negeri Di Ternate. Edukasi; Jurnal Pendidikan, 15(2), 135-146. 